\title{
Migration in the Western Mediterranean
}

The upheavals of the Arab Spring grabbed the world's immediate attention, and concern quickly grew over their potential aftermath, with the fear that a 'tidal wave' of immigrants and refugees would 'flood' European territory. The Arab Spring has highlighted the Mediterranean as a migration region, and new research is now required to bring to light too often neglected mobility patterns and border practices that predate and outlast the tumultuous spring of 2011.

The edited volume Migration in the Western Mediterranean tackles these contemporary issues related to migration in the Mediterranean region. It brings together high-quality, original academic contributions from both empirical and theoretical points of view by scholars from diverse disciplines, who draw upon Anglophone, Francophone, Spanish and Italian research. It re-examines borders in the light of a now full-blown body of literature that seeks to capture the complexity of their contemporary features beyond their most direct visual enactments, in particular the sweeping deployment of policing devices and operations along the North/South fault line. Another distinctive binding thread in this book is that it emphasises migrants as active subjects interacting with local events, national policies and the bordering process.

Offering an examination of the intricate interplay among the events of the Arab Spring, migration's multiple types and actors, and the evolving relationship between migration control and borders in the region, this book is an essential resource for students and scholars of migration studies, European Union Studies and Mediterranean Studies.

Laure-Anne Bernes holds a PhD in Political and Social Sciences from the University of Liège. She is currently an external scientific collaborator at the Center for Ethnic and Migration Studies at the University of Liège.

Hassan Bousetta is currently a Research Associate at the National Fund for Scientific Research, member of the Center for Ethnic and Migration Studies and Associate Professor at the Faculty of Social Sciences of the University of Liège.

Caroline Zickgraf is Research Fellow at the National Fund for Scientific Research and at the Center for Ethnic and Migration Studies, University of Liège. 


\section{Routledge Advances in Mediterranean Studies}

1 Women and Knowledge in the Mediterranean Edited by Fatima Sadiqi

\section{Turkish-Greek Relations}

Rapprochement, Civil Society and the Politics of Friendship

Leonidas Karakatsanis

3 Party-Society Relations in the Republic of Cyprus

Political and Societal Strategies

Edited by Giorgos Charalambous and Christophoros Christophorou

4 The Politics of Culture in Turkey, Greece and Cyprus Performing the Left since the Sixties

Edited by Leonidas Karakatsanis and Nikolaos Papadogiannis

\section{Migration in the Western Mediterranean}

Space, Mobility and Borders

Edited by Laure-Anne Bernes, Hassan Bousetta and Caroline Zickgraf 


\title{
Migration in the Western Mediterranean
}

Space, Mobility and Borders

\section{Edited by Laure-Anne Bernes,}

\author{
Hassan Bousetta and
}

Caroline Zickgraf

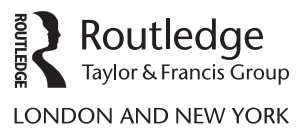


First published 2018

by Routledge

2 Park Square, Milton Park, Abingdon, Oxon OX14 4RN

and by Routledge

711 Third Avenue, New York, NY 10017

Routledge is an imprint of the Taylor \& Francis Group, an informa business

(C) 2018 Laure-Anne Bernes, Hassan Bousetta and Caroline Zickgraf

The right of the editors to be identified as the authors of the editorial matter, and of the authors for their individual chapters, has been asserted in accordance with sections 77 and 78 of the Copyright, Designs and Patents Act 1988.

All rights reserved. No part of this book may be reprinted or reproduced or utilised in any form or by any electronic, mechanical, or other means, now known or hereafter invented, including photocopying and recording, or in any information storage or retrieval system, without permission in writing from the publishers.

Trademark notice: Product or corporate names may be trademarks or registered trademarks, and are used only for identification and explanation without intent to infringe.

British Library Cataloguing in Publication Data

A catalogue record for this book is available from the British Library

Library of Congress Cataloging in Publication Data

Names: Bernes, Laure-Anne, editor.

Title: Migration in the western Mediterranean : space, mobility, and borders / edited by Laure-Anne Bernes, Hassan Bousetta, and Caroline Zickgraf.

Description: Abingdon, Oxon ; New York, NY : Routledge, 2017. |

Series: Routledge advances in Mediterranean studies ; 5 Includes

bibliographical references and index.

Identifiers: LCCN 2016048949 | ISBN 9781138101715 (hardback) |

ISBN 9781315656724 (ebook)

Subjects: LCSH: Mediterranean Region-Emigration and immigration.

European Union countries-Emigration and immigration. | Arab countries-

Emigration and immigration.

Classification: LCC JV7590 .M4864 2017 | DDC 304.809182/21-dc23

LC record available at https://lccn.loc.gov/2016048949

ISBN: 978-1-138-10171-5 (hbk)

ISBN: 978-1-315-65672-4 (ebk)

Typeset in Times New Roman

by Wearset Ltd, Boldon, Tyne and Wear 


\section{Contents}

Introduction: migration, mobility and borders in the Western Mediterranean - old spatial divisions, new agenda

LAURE-ANNE BERNES, HASSAN BOUSETTA AND

CAROLINE ZICKGRAF

\section{PART I}

Understanding mobility and borders in the Western Mediterranean

1 The conceptual dynamics of borders in a world in motion RICARD ZAPATA-BARRERO

2 The network-border: the articulation of mobility and immobilisation

ANDREA REA

3 State-bound visa policies and Europeanised practices: comparing EU visa policy implementation in Morocco FEDERICA INFANTINO

\section{PART II}

Migration control and the advent of the Arab Spring

4 Migration in the Euro-Mediterranean area: Lampedusa and beyond 
vi Contents

5 Tunisian migrants' journey through the Mediterranean

AIDE ESU AND SIMONE MADDANU

6 Freedom of movement and dignity at work: from

revolutions in Tunisia and Egypt to migrant struggles in the Euro-Mediterranean space

FEDERICO OLIVERI

\section{PART III}

Transit migration and new mobilities in question

7 Transnational migration is always a migration in stages: the Moroccan stopover of Sub-Saharan migration MEHDI ALIOUA

8 Constructing mobile lifestyles between Europe and Africa: sha'bi Moroccan men and new European nomads 


\section{Contributors}

Ricard Zapata-Barrero, Director of GRITIM-UPF, Universitat Pompeu Fabra, Barcelona.

Andrea Rea, Director of GERME, Université Libre de Bruxelles.

Federica Infantino, Cevipol, FNRS/Université Libre de Bruxelles, CEE, Sciences Po Paris.

Elif Cetin, Department of Politics and International Studies, University of Cambridge.

Aide Esu, Dipartimento di Scienze Sociali e delle Istituzioni, University of Cagliari.

Simone Maddanu, Sapienza University of Rome and CADIS (EHESS/CNRS), Paris.

Federico Oliveri, Sciences for Peace Interdisciplinary Centre, University of Pisa.

Mehdi Alioua, Sciences Po Rabat, Université Internationale de Rabat.

Marko Juntunen, School of Social Sciences and Humanities, University of Tampere.

Špela Kalčić, Slovenian Migration Institute, Scientific Research Center of the Slovenian Academy of Science and Arts, Ljubljana. 
Review Copy Only - Not for Redistribution

Simone Maddanu - CADIS - 12/21/2017 


\title{
5 Tunisian migrants' journey through the Mediterranean
}

\author{
Aide Esu and Simone Maddanu ${ }^{1}$
}

If we think, after all, that the boat is a floating piece of space, a place without a place, that exists by itself, that is closed in on itself and at the same time is given over to the infinity of the sea and that, from port to port, from tack to tack, from brothel to brothel, ..., you will understand why the boat has not only been for our civilization, from the sixteenth century until the present, the great instrument of economic development ..., but has been simultaneously the greatest reserve of the imagination. The ship is the heterotopia par excellence.

(Foucault 1986, 27)

\section{Introduction}

In the second half of March 2011, thousands of undocumented Tunisians reached the coast of Lampedusa, taking advantage of the collapse of border control following the political fall of President Zine El Abidine Ben Ali. ${ }^{2}$ The island facilities, designed for a maximum of 800 people, were soon heavily overcrowded. More than five thousand migrants camped in the countryside, creating an unsuitable situation for both the migrants and the people of Lampedusa. The assistance of the citizens of Lampedusa and the devotion of volunteers and the Coast Guard counterbalanced the Italian government's organisational inertia, demanding a joint European Union effort to cope with the situation. In an attempt to unify the national political spirit and pressure the government to address the difficult conditions of the illegal aliens who had landed in Lampedusa, President Giorgio Napolitano called for national cooperation and solidarity, requesting that other regions shelter the migrants. In the first week of April, the Interior Minister permitted moving the migrants to other detention centres in order to clear Lampedusa. During the displacement procedures, the government issued a decree law allowing local authorities to grant six-month residence permits for humanitarian reasons. ${ }^{3}$

The northern Italian regions, where anti-migration opinion prevails, ignored President Napolitano's call for solidarity. Sardinian local authorities made available a former police centre and quickly adapted it into a reception and identification camp 4 (RIC) to shelter the migrants. The decree law $^{5}$ did not consider this specific group of migrants to be illegal aliens but placed them in a limbo similar to that of refugee status, so local authorities could adopt a flexible policy 


\section{Review Copy Only - Not for Redistribution Simone Maddanu - CADIS - 12/21/2017}

Tunisian migrants' journey through the Mediterranean

regarding their freedom. On 5 April, more than 700 migrants were displaced to Cagliari in Sardinia. Almost all were Tunisians.

\section{Heterotopia and the state of vulnerability}

This research based on direct narrations sheds light on the Mediterranean journey of Tunisian migrants and explores their lives during their stay in the RIC in Cagliari during three weeks in April 2011. The unique combination of three displacements in a short period of time makes the metaphor of the boat acutely meaningful in capturing the complex consequences of these migrants' journeys. Foucault's ${ }^{6}$ embryonic description of utopias and heterotopias has stimulated a deep debate in social and urban sciences; the concept has been explored from several perspectives and given rise to the so-called space turn, playing a key role in urban studies. Heterotopia also animates some conflicting interpretations and criticisms: Soja (1995) argues that Foucault's ideas are incomplete, inconsistent and sometimes incoherent, while Genocchio (1995) raises objections to the extensive application of the concept. Despite these views, as Dehaene and De Cauter (2008) point out, the concept of heterotopia reoriented the debate on urbanity and public space, becoming a source of inspiration, being enriched by the English translation of Levèbvre and de Certeau, and promoting the reinvention of the everyday life and space discourse.

Heterotopias are described as sites "that have the curious property of being in relation with all the other sites, but in such a way as to suspect, neutralize, or invert the set of relations that they happen to designate, mirror, or reflect" (Foucault 1986, 24). These spaces are utopias and by contrast heterotopias. Society and history assign different meanings and functions to heterotopias. In this case study, the fish boat becomes, after the Jasmine Revolution, a means of transportation to the EU border.

Why do we use the concept of heterotopia in this research? Foucault's evaluation of the "ship as the heterotopia par excellence" is our reference point for interpretation. We investigate a stage of migrants' journey (the three weeks spent in Cagliari) as a lull in their floating travels, a juxtaposition (temporal and spatial) that generates other spaces (the encampment, the profiling procedures in the migration office, the public space). The immigrants' semi-free status opens new questions about their social experience of space, the everyday walking practices, the relation with the public space and the contact with a different culture.

Foucault uses the metaphor of the mirror to describe the relation between space and utopia. He considers the social experience of space to be an intersection of simultaneity and juxtaposition, near and far, side-by-side and dispersed (Foucault 1986, 22). Spaces are simultaneously physical and mental. To highlight the physical-mental space relation, we refer to the daydream as the territory of utopia, the imaginary of a better life in the future (the mental space) and the daily experience in the city (the physical space). The dialogue between the inner space (the dream to succeed) and the heterotopia creates a mixed experience (Foucault 1986, 24) in which dream, memory and courage melt together to 


\section{Review Copy Only - Not for Redistribution Simone Maddanu - CADIS - 12/21/2017}

\section{6}

A. Esu and S. Maddanu

create this human experience. Hope represents the opportunity beyond existing reality, feeds the "utopia [that] afford[s] consolation" (Foucault 1986), and bypasses fear (Bloch 1996, 3). Ernst Bloch, reflecting on the ways to survive in Nazi concentration camps, identifies the daytime dream as a strategy to balance hope and action for change. Illegal migrants live in a state of permanent, nagging fear that does not abandon them until the end of the journey (Laacher 2005, 120). Utopia helps them cope with this feeling. In this case, the semi-free status helps to develop the dynamic relation between the physical and the mental space; utopia expands as much as fear and frustration increase. The daydream soothes migrants' affliction. At the same time, the walking practice brings them back to a concrete living space and links them to a social reality, the relation with a concrete space curtails the utopia, and thus fear can be appeased.

"Camp-like situations" (Dehaene and de Cauter 2008, 5) are the new frontier of heterotopic studies that pay attention to the transformations in everyday life and to the state organisations engendered by the securitisation process. Following Agamben's (2003) definition of the state of exception as a life in a space where the law is suspended and as a place of exclusion where private and public life are separate, Dehaene and de Cauter $(2008,5)$ declares "the camp [to be] the grimmest symptom of a postcivil urbanism". Migrants are embedded in a precarious reality, experiencing a camp-like situation. They are subject to the biopower practices, to the whole set of technologies formed to discipline and govern normativity (Foucault 1979). Migrants' vulnerability comes up against the governmentability; they are at the core of the process of "a model for conceptualizing power in its diffuse and multivalent operations, focusing on the management of populations, and operating through state and non-state institutions and discourses" (Butler, 2004, 51). They undergo a set of dispositifs based on the logic of exclusion, collecting the information and profiling to classify social groups and frame who is in or outside the normal. Normality and deviance are reframed by the emerging codes of the securitisation process; but the technologies of surveillance applied against state vulnerabilities and threats (migrants, terrorists) reveal a lack of care for legal and social guarantees (Bigo and Tsoukala 2008).

The migrants who landed at Lampedusa are involved in these securitisation practices. In this case study, the RIC camp is like a "waiting zone" (Bigo and Tsoukala 2008, 37), where securitisation practices are applied in order to issue six-month residence permits. The period of time (three weeks) is too short to allow for the creation of the complexities that characterise social relations in refugee encampments, including tensions and suffering (Agier 2008). The semicoercive lifestyle in the RIC has common features with Goffman's concept of total institutions. RIC structures can be considered a contemporary form of the total institution as a formally administered place of residence and work (Goffman 2001). In the RIC, the work dimension - prisons and asylums in the case of Goffman (2001) - is less relevant than in the classic description. The institutionalisation process affects notions of self, the meaning of the loss of security, and the system of privileges which compensates for and controls anxieties generated by the spatial and temporal upheaval of the exile condition. 


\section{Review Copy Only - Not for Redistribution Simone Maddanu - CADIS - 12/21/2017}

Tunisian migrants' journey through the Mediterranean

\section{The fieldwork's heuristic}

Within this theoretical framework, the research explores migrants' inner space from different perspectives: their journey biographies and precarious life waiting for the delivery of temporary papers, their mixed feelings of fear and hope in the condition of limited rights and threatened annihilation, and their walking practices as a way to manage identity dispossession and fear. Considering that the state of exception begins at the moment of disembarkation in Lampedusa (identification and depersonalisation procedures, deportation for those under police records), we examine migrants' identity trajectories: the decision to leave the homeland, the heterotopic experience of being here and elsewhere in a situation of high insecurity. In their migration journey, Cagliari is a stage of forced relocation following the evacuation of Lampedusa, a time of deferral in their lives spent waiting for a temporary passport. Looking at this case, it is evident that geographical dislocation plays a basic role in the memory of the journey: the village, the place of departure, the Mediterranean crossing in an overcrowded boat, the disembarking, Lampedusa; the evacuation, the 48 hours in a boat garage waiting for a new location; ${ }^{7}$ and finally the landing in Cagliari and, then again, the crossing of the sea for a new destination in Europe. It is clear that the exodus followed by a shaky landing in the middle of the Mediterranean and forced displacement to an unknown place exposes the migrants to an extraordinarily heterotopic situation.

The weak limitations on migrants made them visible in the city. The first day, they colonised the RIC's surrounding area in a continuous flow of inquiries and observations about the new place; day by day, their exploration became fearless until they reached downtown. This crucial event drew our interest, and we explored the practicality of doing research on this migration stage. We met migrants during their outings from the camp in the north-western area city. We had daily appointments in Sant'Avendrace square, the migrants' first stopping point while discovering the city. We walked with them, sometimes wandering aimlessly, crossing the city before returning to the camp again. The discussions, questions and answers, both theirs and ours, were developed along a track from a café near the camp to downtown, sometimes walking for hours. The methodological choices were gradually made pragmatically, adapted on a day-to-day basis due to the uncertainty caused by local authorities' daily agenda. We contacted the migrants at the entrance to the RIC, on the streets, at the police migration office and along the dock, observing the boarding procedures when they left the city. Every single choice was governed by this unpredictable agenda.

Gradually, an urban ethnography took shape. We triangulated the data with ethnographic methods, such as observations, interviews and spending time together in the city. The participant observation was tailored on a daily basis by the field practice. We walked with the migrants through the city and became familiar with some places, soon identifiable as meeting points. At the end, we could draw a map of the migrants' urban mobility and meeting places. The daily field practice reinforced cooperation, trust and reciprocity; we shared 


\section{Review Copy Only - Not for Redistribution Simone Maddanu - CADIS - 12/21/2017}

\section{8}

\section{A. Esu and S. Maddanu}

information, growing the mutual ethos of trust. The migrants needed information about Italian politicians and decision-makers and the EU policies regulating the process of the obtaining temporary passports that would allow them to circulate in the Schenghen area. Reading and translating the newspapers became a daily routine. Ethnographers formulated the idea of the "trust game" (Cardano 2011, $126)$ as a strategy in the field research setting to build relationships with informants. Our trust game was played in the daily translation of newspapers, which strengthened the climate of mutual sharing and open dialogue upon which we built the heuristic of observation. We collected information through a stream of mutual exchanges, such as accounts of "What [do] people in the city say about us?" Unable to enter the camp which was inaccessible to unaccredited visitors like us, we decided to collect descriptions of the camp through the migrants' voices. We gradually reassembled the narrations composed through fragmented discourses gathered in repeated daily talks, short interviews, conversations and information exchanges. The narrative flow was strongly affected by the migrants' emotional state. We decided not to force their accounts through lengthy questioning; we preferred to let them feel free to tell their stories in a more discursive way. The obsessive repetition of the word 'stress' testified to their emotional condition and revealed an obstacle to explaining their present situation and the inability to face their disheartening state. Migrants were beset with daily worries related to the issuance of temporary residency permits and tormented by uncertainty about authorisation to circulate in the Schengen area. The camp surveillance devices and rules curtailed individual will and desire; migrants were powerless witnesses of their present and frustrated by the inability to plan their future. Sharing information was crucial in their routines, even if it meant a tiring, distressful balance between the need to know and the fear of knowing.

\section{The journey, from harbour to harbour}

When we meet them, they smile. They look happy and glad of the city's welcome: "Beautiful city. People are nice", they say. When we mention the journey from Tunisia to Lampedusa, though, they do not smile anymore. Often, they repeat the word "bad" (mauvais). Ali becomes our main informant. He is a 30-year-old man from Djerba, who has crossed the Italian (and so the European) border ten times, so he is a veteran of the illegal immigration. Within a week, Ali, like his 700 companions, embodied Foucault's sense of heterotopias: the journey from Zarzis to Lampedusa, the stay on the island, and then the transfer to Cagliari and a temporary arrangement at the camp. We met him outside the camp. He is alone, sitting on a bench and smiling at the people walking by. He is apparently trustful, perhaps because it is his first day of freedom in the city. He does not have any money, and no one was going to lend to him, but he was hopeful about this journey. Like the others, Ali's dream is to live elsewhere. He had worked as an entertainer in Djerba to save money so that he could leave whenever he had the opportunity. Perhaps the recurring, internal sense of fear 


\section{Review Copy Only - Not for Redistribution Simone Maddanu - CADIS - 12/21/2017}

Tunisian migrants' journey through the Mediterranean

(Laacher 2005) in the migrants' discourses reflects the tangle of emotions experienced since the departure, and the journey's memory: the wind, the seawater, the fear of sinking. Even after two weeks of daily meetings, few answer questions related to the crossing between Zarzis and Lampedusa. Mustapha, like others, cannot swim and had never seen the sea. Some tell us that they took seats beside those who could swim. ${ }^{8}$

I'm not able to swim.... The sea was rough. But we survived, didn't we? I don't know what would have happened if things had gone differently.... [laughing] But I'm here now, aren't I?

(Mustapha, 19 years old)

During the crossing, everybody was speechless. Fear and loneliness were common feelings in the crowded boat. Some migrants survived high risks with a flooded engine, including Hamza who spent 48 hours in the water with the boat's motor cut off due to engine flooding. Only Hamza attempts to express the meaning of the word "bad" (mauvais).

Why did I convince myself to leave? Why, why? If you offered me 10 million dinars to do the crossing again, I would answer you 10 million times no!

(Hamza, 23 years old)

Before the harraga, ${ }^{9}$ others like Ali waited for years for the right opportunity. The migrants' syncopated narrations tell of a Mediterranean odyssey, followed by endless, suspended lives moving from port to port, and the memory of floating, the mirror of their distressful conditions. The passage from Lampedusa to Cagliari was no less tragic than the crossing from Tunisia.

Three days between Tunisia and Lampedusa. Then, they took us to another boat [ferries]. The all seven hundred people! Into the boat car park, with nothing, just sitting on the iron floor... It was so hard, with all these big bolts! ... Two days and two nights, in front of Civitavecchia and then Cagliari ... But, is Cagliari an island? ... So, after [all] we [will] have to take the boat again! [laughing].

(Moustafa, 19 years old)

Such fragmented flashbacks occur when we ask, "What about the crossing from Tunisia?" Crossing the sea intensified disorientation. People from rural areas sometimes do not have good geographical perceptions of Tunisia or their next destination. This confusion appears when they ask about the geographical location of the city or request us to draw a map of France.

Ali, as a veteran of the harraga, is very good at hiding his fears and prefers to show hope and optimism. His past migration failures seem to be ignored by his fellow companions who are persuaded that "each journey has its own story" and 
"everyone tries to grasp his own chances" (Alì, Nader, Mustafa, Hamza), like a personal God for everyone, an opportunity for everybody. ${ }^{10}$

\section{Exploring the city: flâneur or semi-free men?}

During the first days of exploration, the migrants' path follows a linear trajectory, going back and forth in the same way. As they become familiar with the city, their trajectories become circular and fragmented and let them get lost in downtown's narrow streets and alleys and move into other areas, such as the seacoast along the harbour. Migrants explore the city, looking for a bank willing to change dinars to euro and seeking a public telephone, and very often find that Western Union and Money Gram offer the same services. Once migrants become familiar with the places and feel secure, we can fix appointments in downtown. Often, we do not schedule appointments but meet in the Sant'Avendrace cafés where migrants feel comfortable or simply wherever a group decides to stop at random. Day by day, the spatial meanings, as de Certeau (1998) defines them, take form according to the pattern fixed by the urban design (149). The urban design influences and orients path choices in the RIC surroundings. The camp is in the first section of Viale Elmas, the arterial road leading into the city. For decades, it had been a lawless place on the city periphery and remains a hybrid area, half-suburban but without any sidewalks. The migrants take a safer minor road, and Sant'Avendrace Avenue becomes their main way into the city. Following de Certeau (1998), the pedestrian speech act "actualizes only a few of the possibilities fixed by the constructed order (he goes only here and not there)" (98). Thus, in their urban experience, migrants re-create "a near and far, a here and a there" (de Certeau 1998, 99) related to their walking style. First, they explore the area near the RIC, "colonising" the surrounding roads and stopovers along the perimeter of the camp's fence. The migrants' movements make this place visible to journalists and citizens who cross into the area to interview them or offer some aid. Stability - as Mitchell $(2002,177)$ interprets the sense of place in de Certeau's thought - assigns a precise connotation to this localisation. Soon, this place is labelled the Tunisian camp.

Walking with migrants, confirming their viewpoints and smoking cigarettes with them supports the trust game (Cardano 2011), even if the conversations do not follow the research aims. Questions and answers occasionally appear disconnected and extemporaneous. Sometimes migrants answer serious questions in an ironic manner. Often they seem to minimise both past and present dramatic events and future risks and uncertainties. Some inquiries remain unanswered, and the outcome of migrants' journeys seems to be a matter of fortuitous events or wishful destiny, rather than personal action and will. They downplay and take pleasure in their semi-free status, and their need to leave behind the harsh days in Lampedusa makes them feel better. "We are like tourists in Sardinia", say Ali, Ramzy and Nader, taking photos with a cellphone and offering drinks to the group of six in a bar. They feel a little bit at home: Cagliari is Mediterranean; "it's almost Tunisia". 


\section{Review Copy Only - Not for Redistribution Simone Maddanu - CADIS - 12/21/2017}

Tunisian migrants' journey through the Mediterranean

Repeated walking makes them familiar with squares and roads, and they feel safe in exploring the city. Day by day, they create a personal "rhetoric of walking" (de Certeau 1998, 100), which makes it possible to capture their style: alone or paired, or grouped, walking through the same roads. As well, being visible overcomes the concept of the rhetoric of walking, and they become part of the landscape, though discernible as the "Tunisians from Lampedusa". The local media's attention is focused on the unusual situation in the city, and daily

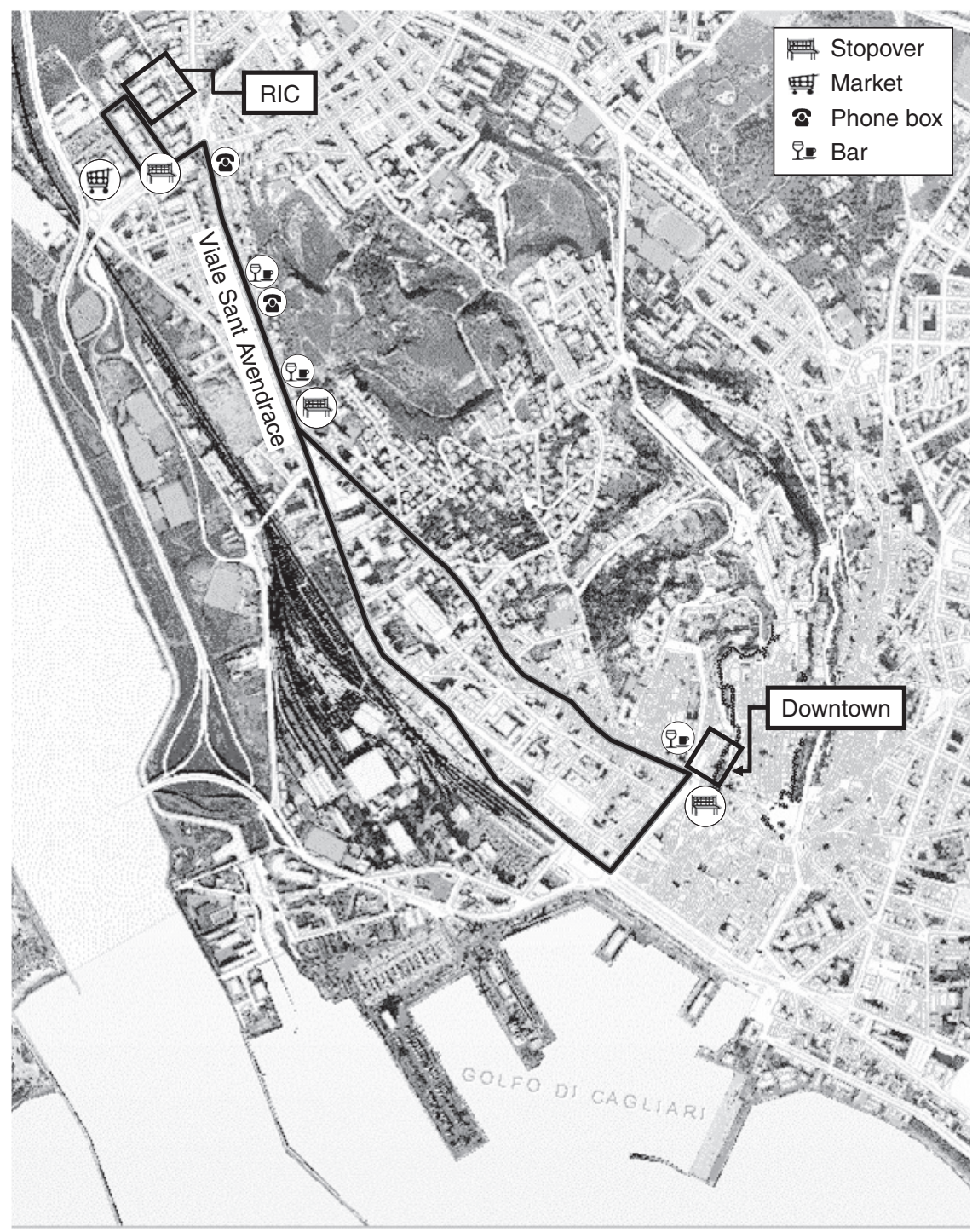

Figure 5.1 Migrants' urban trajectory. 
accounts of legal procedures and citizens' reaction to the migrants' presence appear in the headlines. Within two weeks, locals become familiar with these young men hanging about in the city, and the migrants thus become less visible but still contribute to changing the social space. The city's reaction is highly positive, locals are proud to show solidarity, and groups of citizens visit the RIC area to offer food and clothes in the first days of the migrants' stay. During their stay, three minor cases of conflict with the local population are reported.

Walking downtown or discovering the arcades along the seaport, the aesthetics, architecture and beauty of this Mediterranean city ease the migrants' future expectations. Tunisians are highly visible downtown because they all dress in the same clothes handed out by Caritas (a non-governmental organisation); some wear Montana University sweatshirts and white shoes with the Italian flag. Once they catch a smile or other sign of approval, they stop hiding their identity, age and reason why they left Tunisia, as they had done in Lampedusa. By now, their only secrets are their personal, intimate dreams, hopes and fears. Their repeated thoughts concern the Italian government's decisions and the daily news about how to manage the next stage of their journey. They are wishful, of course, saying "Insh'Allah" (if God wills). Their daydreams surface from time to time. The discourses of hope and dream are mixed in Ali and Najah and clearly appear in the form of possibilities that go beyond actual reality.

How many days will they keep us here? Anyhow, I have to go to France. In Paris, I will find a job. Is there work in France? ... I'm able to do everything: house painter, bricklayer.... I can also work in catering or as a mechanic.... Then, I could find a woman to get married.... I will stay in France until I have earned enough! ... Once I have arrived in France, I will be able to send money to my family. I have to pay back!

(Ali, 30 years old)

I have to go to Oslo. Then I can get married to my girlfriend. She is older than me. I met her in Djerba last year, and she told me to join her [in Oslo]. Just before, I called her to say I'm in Cagliari. She was very angry [laughing]... But she was angry because she was afraid I could have died.

(Najah, 26 years old)

Flâner throughout the city relieves the migrants' anguish and fear of failing. Failure means repatriation. The bravery, the courage to make the dangerous journey is the result of self-deception, of self-persuasion. They show levity in describing their choices, but they prefer not to talk about the terrible risks of those choices. To reach the other side of the Mediterranean, they took the risks of passing through the securitisation process, such as possible detention. The journey in an overcrowded, tumbledown fishing boat - a Dantesque Charon that cost 700-800 euro - was the worst memory of the migrants' harragas. The journey means separation from their previous life and required the courage to 


\section{Review Copy Only - Not for Redistribution Simone Maddanu - CADIS - 12/21/2017}

Tunisian migrants' journey through the Mediterranean

end their precarious lives in Tunisia, as they describe their everyday life, waiting for better economic opportunities and more freedom. They tell us how difficult living in Tunisia is, even doing simple things like having a drink in a different city or stopping in a square. Looking at what they have left behind, the migrants truly appreciate their state of semi-freedom. As Najah says:

Here [downtown Cagliari], we are able to drink coffee peacefully. There is the freedom here. Ah, the Italian coffee ... We went to Monastir, and they [police] turn us away. They said, "What are doing here? Why are you at the bar? What do you want? Go back home!" Sometimes they bring you to the barracks. They hit you. Do you see my shaved head? I was in the bar when they brought me to the barracks. I stayed there for 42 hours. Then they shaved my head and they sent me back home.

(Najah, 28 years old)

Walking through Cagliari's streets, being able to have coffee in a bar and enjoy life in public places, and being a free person are the Tunisian migrants' therapeutic remedies. The habit of walking daily transforms the place from hostile to familiar, makes the space friendly, and improves the embodiment of space (Leroi-Gourhan 1964). Then, migrants can create the imaginary of a journey in a safe place. As they become familiar with the path from downtown to the RIC, they explore the narrow streets of the Marina, the old fishermen's neighbourhood. They discover a friendly city and popular tourist attraction with outdoor space and people standing in terraces and squares but also quickly come across the other side of Cagliari: the jobless workers' union pickets. ${ }^{11}$ Although Cagliari appears to be a pleasant, amiable city with a familiar landscape, migrants are aware that Sardinia cannot be their last destination.

\section{Precarious lives: the day-by-day hope}

What happens in the camp remains largely unknown to us. Except for the police, only Caritas volunteer workers in charge of aid can freely enter the camp. The stories we report come from the migrants' narrations, so accounts of the camp's everyday life are incomplete and full of omissions. However, we can point out some elements. Along with walking around the city, mealtimes (breakfast 8 a.m.-10 a.m., lunch 12 p.m.-2 p.m., dinner 6:30 p.m.-8:30 p.m.) mark the daily rhythm in the camp. The camp authorities take advantage of mealtimes to give and receive general information. During the emergency, the local authorities had quickly rehabilitated an abandoned military barracks, so all 700 illegal migrants are placed in two large rooms and some medium-sized rooms equipped with bunk beds. Outside, a huge playground allows some to practise soccer. The barracks area is outlined by a fence. The migrants' ambiguous legal status which leaves them in the category of asylum-seekers allows them to come and go from the camp as they wish. However, a few days after their arrival, some restrictions are imposed on the use of the main door. The migrants slash the fence, and by 


\section{Review Copy Only - Not for Redistribution Simone Maddanu - CADIS - 12/21/2017}

\section{4}

\section{A. Esu and S. Maddanu}

hanging onto an electricity pole and leaning against an uneven wall, they can reach the breach and open the gate.

Waiting for their temporary papers, the migrants sit on the camp courtyard chain-smoking cigarettes distributed by volunteers. The majority of the migrants follow al-zuhr, the Islamic Friday prayer. Very few pray daily. Sari, a 25- to 30 -year-old man, is accepted by the migrant community as its temporary imam. Sometimes, the group makes jokes about his long, bushy beard. The imam is perhaps one of the few people who never leave the camp. It is rumoured that "he doesn't want to fall into temptation.... He wants to preserve his integrity" (fieldwork notes). Sari's moral leadership is accepted and appreciated, especially when he tries to cool down the recurring fights, mostly in the evenings and often exacerbated by high consumption of alcohol and the lack of privacy. The migrants' reports upon returning to camp serve to create Sari's city imaginary. Generally, the role of religion seems to be limited. Camp authorities observe Islamic dietary rules, offering halal meat and fish, in addition to rice and pasta. Migrants can live religion in their personal manner, and it is rarely used to emphasise differences. However, for the migrants, it is crucial to accomplish their purpose, their dream, and thus they move in an intangible space between chance, will and destiny. "Insha'Allah, God willing", they repeat. They leave their lives in God's hands, hoping that he will be merciful and forgive their sins. Sometimes the migrants seem to make a vow of religious return once their dream of a stable life and stable work is accomplished.

The RIC is a hybrid detention body. Migrants are aware that the camp is a shelter for sleeping, food, cigarettes and clothes, but above all, they are aware that respectful behaviour is the only way to obtain the temporary resident papers. For those who spend their time in the camp, it is also a place for debating, where they reflect on their daily experiences. However, for those without a cellphone, it is a lonely cage. It is a place where frustrations due to the state of uncertainty lead to fights and aggression against the authorities or among migrants. When discouragement wins out, migrants lie in bed all day long, trying to overcome the stress and the depression. That is how Ali's fellows explain his absence that day.

Today, Ali stays in the camp. He stays in bed. He does nothing.... He tosses and turns. He didn't want go out. Too much stress! Too much stress [laughing].

(Nader, 23 years old and Ramzy, 25 years old)

Anxiety and hope are the two main feelings of the illegal aliens waiting for their temporary papers. Sometimes, in their distressed state of mind, sorrow, pain and hope overlap. Quick changes of mood depend on the unpredictable decisions of the authorities; waiting for papers is like living in limbo. The migrants' suspended rights are (Butler 2004, 13) the core experience of their everyday life, even if the freedom to be in the city mitigates this state of mind. However, migrants still remain subject to the devices of the microphysics of power. The 


\section{Review Copy Only - Not for Redistribution Simone Maddanu - CADIS - 12/21/2017}

Tunisian migrants' journey through the Mediterranean

daily rhythm of breakfasts and other meals, the control procedures, the recording of personal information, the assignment of a new identification number, all are beyond the migrants' control. They know neither how long they will stay nor where they will be allowed to go: the Schengen area or in Italy. Their hope needs to be fed by imagining a better life. Their tangible reality is the camp's micro disciplines: the daily controls and profiling procedures, the internal tensions between migrants fuelled by alcohol, and the absence of privacy in the overcrowded space. The rising tensions take a political turn when two hunger strikes are held to protest the lack of information and recognition of migrants' rights in the camp. The fear of forced repatriation to Tunisia keeps returning. The semicoercive life in the camp calls attention to some features of Goffman's concept of total institutions. First, the dispossession process resulting in the deprivation of the identity toolkit is manifested in identification devices. Names disappear from ID badges, and a personal identification number becomes migrants' new ID, referring to a personal file. Identity traces are stored in police memory devices, gathering detailed knowledge about migrants' lives ruled by the state of exception.

The meaning of the loss of security for inmates (Goffman 2001, 51) is voiced in the questions that fuel their anxiety and stress: "What do they know about me? Why do they require all this information? Why are they taking my fingerprints?" Stress, a theme so often repeated in their narratives, is the accumulation of the risks undertaken: the perilous navigation, the landing, the mortification of self by the state of exception devices, and the lack of privacy in the camp. Like the classical description of the inmates' world, their anxiety fosters a sense of helplessness regarding their wishes. We find a system of privileges (Goffman 2001, 83), the camp management makes concessions such as a tolerant attitude towards of the fence breach or the distribution of cigarettes in order to contain internal tensions.

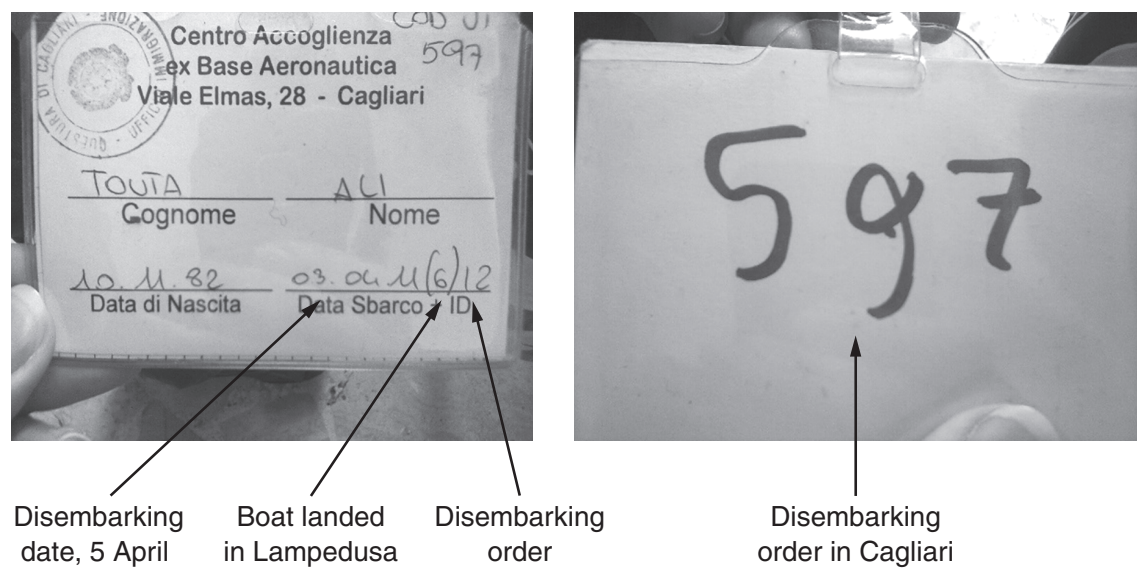

Figure 5.2 Provisional ID.

Source: authors. 


\section{Review Copy Only - Not for Redistribution Simone Maddanu - CADIS - 12/21/2017}

Migrants ignore the government's intentions and are kept in a state of anxiety due to this lack of information. Reading newspapers with us helps control this state of mind. The information received prompts some to reassess their future projects or re-evaluate the concerns, questions and hopes, as Alì and Jamal do.

... What does Sarkozy say? If he doesn't allow entry... And to Milan? Otherwise, I can go to Milan, just to find a job ... after, with the papers ... anything [as job]. Then, if I get a job, I can get the papers ... after I'm able to go to France...? ... Otherwise, if I like Milan, I could stay there.

(Ali, 30 years old)

Berlusconi is a good guy! I know, [laughing] he's a bit like Ben Ali. But he [Berlusconi] said we could go to France. It is Sarkozy who does not want us. What is the name of the minister who said that? ... In one way or another, [I'll get to France]. Can we go to Belgium? And what is the best route to take?

(Jamal, 32 years old)

Since their departure, the migrants have endured corruption, lies and legal violations. They paid local mafias for an uninsured, one-way ticket. Migrants know very well the illegal ways to cross European borders. They know, or they learn quickly, how to adapt to tough circumstances and how to manage no-win situations. The ruse and the arrangement are not the exception. They need to find an Italian phone card and to withdraw the money sent from Tunisia without an identity card. Since the first days after the migrants' arrival, some (among these regular migrants living in Cagliari) have offered them fake employment contracts, useful for getting a year-long residency paper. These contracts are sold in Tunisia for approximately 3,000 dinars or 1,500 euro, but in this emergency situation, the price rises to 2,000 (3,500 euro)..$^{12}$ According to the migrants interviewed after they had left Cagliari and arrived in France, many illegal aliens, not only those who arrived recently in Lampedusa, travel to Italy to buy fake employment contracts. The price is between 1,000 and 1,200 euro for a year-long contract, plus 60-100 euro for a monthly salary invoice and more than 300 euro for fake permanent papers. Migrants work off the books to collect the money to buy a fake contract. They are the pillar of this contract market, usually run by Italians and North Africans. Migrants seeking legal status are the greatest feeders of this illegal system. The migrants with whom we talk are not shocked at all by this system; they are aware that they are the victims of this market, prisoners in this vicious cycle. They are disenchanted by justice in Tunisia, and it is clear that the corruption of politicians and law officers puts the migrants in the category of lawbreakers. Some describe breaching legal behaviour in order to obtain a public good as white lies. They do not feel they are in the wrong but, rather, taking a risk in order to get the opportunity to succeed in Europe, ${ }^{13}$ even by means of white lies. White lies are useful and necessary, sometimes the only way for migrants to achieve their dream as victims of untrustworthy institutions and justice. 


\section{Review Copy Only - Not for Redistribution Simone Maddanu - CADIS - 12/21/2017}

Tunisian migrants' journey through the Mediterranean

\section{Talking about revolution}

The research took part in the aftermath of a crucial historical moment for Tunisia and, by viral effect, for the entire Arab world (Castells 2012; Khosrokhavar 2012; Lynch 2012). In this context, talking about the revolution was unavoidable. We collected some information related to the uprising and the opportunities opened by the lack of border control. We report some significant opinions that reveal an interesting vision of the revolution, far from the one portrayed by international media.

The migrants' reasons for leaving their country are various, often individual goals that reflect family hopes. The main motivation remains the desire to improve economic conditions. The recurring answer to the question "why leave now?" is that they took advantage of weakening surveillance during the Ben Ali transition. Leaving now is seen as a way to catch an opportunity, sometimes without enough planning, as Ramzy testifies.

My cousin told me there was enough place for two, three people for the next night. So I said goodbye to my friends, I took the money I had saved, and I left.... I called my mother when I was here [Cagliari]. She cried. My father was angry ... But my brothers were happy, and they encouraged me.

(Ramzy, 25 years old)

The stories about the days of Tunisia's Jasmine Revolution stay shrouded in secrecy. ${ }^{14}$ No one among the migrants is talkative about or proud of the uprising. They tell us of being part of the street uprising, as they call it, but show disenchantment about the revolution's goals and results, as seen in Amar's testimony.

What revolution? There wasn't any revolution.... Ah, yeah, I understand. On the streets ... against the police. Of course, everybody was on the streets. We stayed for three days on the streets. We smashed everything, we set [things] on fire.... After, the police left ...

(Amar, 26 years old)

Unlike the general interpretation portrayed in media coverage, the uprising does not appear to the migrants to be a turning point, or tranchant (Ricœur 1991), in their country's recent history and current situation. The mistrust of the Tunisian ruling class and the weak institutions pushed them to consider migration to build a better life in Europe as their only hope.

Of course, Ben Ali's downfall is great! He was a dictator. Corruption! You couldn't do anything without the Trabelsi clan's permission. ${ }^{15}$ They stole everything.... So now, what do you think you could do in Tunisia? They still are there. And there is nothing; it does not work. I went to the streets to protest. 
The group we met in Cagliari does not seem to be ready to act in the democratic reconstruction of their country. They do not believe in its potential, and they never practiced politics; their material needs are too urgent, and they do not imagine themselves as actors in the present and the future of Tunisia. Being in the street did not have an exclusively political meaning. Migrants' accounts of those days testify to a spontaneous participation and the expression of the need to occupy a meaningful public space, to join an uprising, and to acquire the opportunity to share in the new situation. Attending rallies, they grasp the historical moment as a social and individual need, even if they cannot attribute any political interpretation to it. They seem to accept a subordinate role in this historical moment. They prefer to leave and try their destiny by crossing the sea and following the dream of a new life. Our questions reveal to them how the Tunisian turmoil drew interest and made sense beyond the Tunisia borders. They answer our questions, quite surprised that "we knew about them", about their facts and the events. Our questions make them feel like key social actors, and we probably encourage them to present themselves in that way. Perhaps, talking about these events in a new way raises doubts regarding the meaning of these actions. The topic of the post-Ben Ali reconstruction makes them most reflexive, especially when we ask why, if they took part in the uprising, they left Tunisia.

The Revolution? Ah, Ben Ali? Ben Ali ran away. But nothing has changed... Yes, something will change, but not now. Now there is a critical situation. Police aren't there as before ... All Tunisians were on the streets! [laughing] To change really, that needs at least four years, definitely. After, maybe ... living in Tunisia will be great. Maybe I'll come back. But now, what can I do? There is nothing to do in Tunisia. We have to wait.

(Mustafa, 19 years old)

Reflecting on migrant identity, Sayad (1999) points out the conflicting mindset of simultaneously being a migrant and an immigrant. He elaborates on the concept of migrants experiencing a "double absence" from the sense of absence from their native society and a lack of responsibility to that country. The migrant, though, remains an outsider in the host society, where he is perceived only as part of the labour force subject to a conditional and revocable residency status. In this context, Sayad (1999) elaborates on the idea of blame originating from the double absence. Once again, migrant blame (Sayad 1999, 25-51) resurfaces, a feeling of incompleteness which illegal migrants might deliberately deny in order to keep determination to reach their goals strong in their minds. This sense of blame is an active element in the fear of being forced to repatriate. These migrants might experience a double frustration: the inability to change their life and find a new destiny in Europe and the denial of their own responsibilities in the search for a new, collective destiny in Tunisia. 


\section{Conclusions}

In this analysis of Tunisian migrants' experiences, Foucault's concept of heterotopia is useful to highlight the complexities of migration life events. To move freely and discover the city helps migrants to escape RIC rules and impositions, enjoy a little consumption of goods, interact with people other than the Tunisians and RIC personnel, and carve out a break, a little independent space. The opportunity to find the space for freedom provides a temporary anchorage from which to reflect on their experiences. Projecting a future life in a day-dream dimension helps migrants to accept their present, everyday experience.

Dreaming of a new life is a way out from the anxieties that fill the migrants' minds. Bloch $(1996,91)$ points out the significance of will and the need for dreaming in order to strengthen the chance of surviving. The migrant keeps the dream secret along the journey; the silence protects this nourishment for the soul during the mute crossing from Tunisia and in the voiceless life in the camp. If Sayad (1992) highlights the "original blame" carried by the migrant in every act of migration, we might say that this case study points to another migrant blame. We studied migrants' experience of a middle earth. They left Tunisia in the aftermath of Ben Ali's downfall, and at this stage of migration, the conflict between migrant and immigrant status had not yet erupted. In the migrants' attitudes towards the Tunisian Revolution, we recognise moral ambivalence or indifference, attributable to knowledge denial (Cohen 2002, 129). Migrants maintain a distance and virtual blindness of the political implications; they take the opportunity to leave the country, even through an unsafe journey, preferring to concentrate their efforts on their personal project. While in Cagliari, they focus their goals on building their individual fortunes in Europe, thinking of how to accomplish the personal dreams rather than engaging in a collective project for the future Tunisia.

However, migrants still participate in this collective search for human dignity, ignited in Tunisia and rapidly spreading throughout North Africa. The uprising is not a revolution in classical political terms as the world media defines it; we agree with Khosrokhavar's (2012) interpretation of it as political action to support human dignity to overcome religion and community defence (Umma). These events can be interpreted as the first manifestation of an emerging civil sphere (Alexander 2006), where subjective aims are pursued by claiming personal rights and fulfilling the need to choose an individual destiny. The post-Ben Ali migration in the case study we analysed testifies to a transitional process. Earlier migratory phenomenon from North Africa mainly entailed a search for better economic conditions, but today, North African migrants are seeking freedom of movement, even if the first stage involves illegal migration and being subject to the control of Western surveillance powers. The Tunisian revolution intensified participation in a larger process intertwined with individualisation, globalisation and politics that places the individual experience in an experimental sphere outside stereotypes and classical life models (Beck 2000, 169). 


\section{Review Copy Only - Not for Redistribution Simone Maddanu - CADIS - 12/21/2017}

The migrants arriving in Lampedusa in the early days of April 2011 could not wait for institutional transformation. They put their lives at risk, not for democracy, but for urgently needed, individual changes.

\section{Notes}

1 Aide Esu wrote 'Heterotopia and the State of Vulnerability', 'The Fieldwork's Heuristic', 'The Journey, from Harbour to Harbour' and 'Exploring the City: Flâneur or Semi-free Men?'. Simone Maddanu wrote 'Talking about Revolution', 'Suspended Lives: The Day by Day Hope' and 'Conclusions'.

2 International Organization for Migration staff in Lampedusa say that the migrant flow is mixed; although the majority want to work, they largely want to go to other countries in Europe, including France, Germany and the Netherlands. Some migrants say they left Tunisia because they were afraid, citing insecurity and danger (see www. iom.int/cms/en/sites/iom/home/news-and-views/press-briefing-notes/pbn-2011/pbnlisting/situation-in-overcrowded-reception-cent.html).

3 The temporary passport granted free movement in the Schengen area of the EU-26 countries.

4 Three types of structures are used to shelter and assist irregular migrants: centres for first aid and acceptance (CPSA), shelters centres (CDA) and reception centres for asylum seekers (CARA), and centres of identification and expulsion (CIE). Reception and identification camps are an adapted form of the CARAs.

5 On 5 April 2011, the Italian government issued a decree law entitled Misure di Protezione Emporanea per i Cittadini Stranieri Affluiti dai Paesi Nordafricani, which granted six-month residence permits for humanitarian reasons.

6 Foucault sketched the idea of heterotopia in the preface of Le Mots et les Choses (1966) and refined it in 'Of Other Spaces' (1986).

7 After the evacuation from Lampedusa, the migrants spent 48 hours in the boat garage at Civitavecchia's port and, when authorities received the Sardinia administrators' agreement, were moved to the Cagliari.

8 Migrants' quotations reported in this chapter were recorded with respondents' permission during conversations and interviews. The names used are the respondents' real names.

9 The North African migrants used to call the illegal migration harraga, which means 'to burn'. The migrants used to destroy the passport in order to hide their nationality and enter Europe as refugees. In our context migrants keep their documents, even though they hide them in order to feel safe.

10 Laacher (2005) observes that this kind of travel, illegal and dangerous, cannot be done alone. It can only succeed "with others and transported by others", but at the same time, this shared experience becomes a fear shared with the "trip fellows" (Laacher $2005,115)$. This collective fear is the only element that migrants have in common with their companions, and the unique, recognisable tie that makes them a "group of illegal immigrants" (Laacher 2005, 115).

11 The consequences of the economic crisis were especially severe for local industry: the closure of some factories and the resulting layoffs regularly drew demonstrators to the streets. According to Italy's national statistics bureau, unemployment in 2011 rose to 17 per cent and 42 per cent among those 15-24 years old (ISTAT). Sardinia confirms that the negative economic trend has continued, prompting internal emigration to northern Italy or EU countries. As well, in 2011, activists and citizens protested in front of the Regional Parliament of Sardinia.

12 According to our interlocutors' reports.

13 Without an identity card, migrants need to find a trusted person able to serve as their intermediary with Western Union. The migrants communicate the name of the trusted intermediary to relatives in Tunisia in order to send correct money orders. 


\section{Review Copy Only - Not for Redistribution Simone Maddanu - CADIS - 12/21/2017}

Tunisian migrants' journey through the Mediterranean

14 The revolution's actors prefer to call it the revolution for dignity. It started after the self-immolation of a young peddler, Mohamed Bouazizi, exhausted by police oppression that prevented him from working in the town of Sidi Bouzid. The true dynamics of this event are now subject to controversy (see Khosrokhavar 2012).

15 The clan of Ben Ali's wife, Leila Trabelsi.

\section{References}

Agamben, Giorgio. 2003. Stato di Eccezione. Homo Sacer II. Torino: Bollati Boringhieri.

Agier, Michel. 2008. On the Margins of the World: The Refugee Experience Today. Cambridge: Polity Press.

Alexander, Jeffrey C. 2006. Civil Sphere. Oxford: Oxford University Press.

Beck, Ulrick. 2000. 'Living Your Own Life in a Runaway World: Individualisation, Globalisation and Politics'. In On the Edge: Living with Global Capitalism, edited by Will Hutton and Antony Giddens, 164-174. London: Jonathan Cape.

Bigo, Didier, and Anastassia Tsoukala, eds. 2008. Terror, Insecurity and Liberty. Abingdon: Routledge.

Bloch, Ernst. 1996. The Principle of Hope, vol. I. Translated by Neville Plaice, Stephen Plaice and Paul Knight. Cambridge, MA: MIT Press.

Butler, Judith. 2004. Precarious Life: The Power of Mourning Violence. New York: Verso.

Cardano, Mario. 2011. La Ricerca Qualitativa. Bologna: Il Mulino.

Castells, Manuel. 2012. Networks of Outrage and Hope: Social Movements in the Internet Age. Cambridge, MA: Polity Press.

Cohen, Stanley. 2002. Stati di Negazione. Roma: Carocci.

de Certeau, Michel. 1998. The Practice of Everyday Life. Berkeley: California University Press.

Dehaene, Michiel, and Lieven de Cauter, eds. 2008. Heterotopia and the City. New York: Routledge.

Foucault, Michel. 1966. Les Mots et les Choses. Une Archéologie des Sciences Humaines. Paris: Editions Gallimard.

Foucault, Michel. 1979. Naissance de la biopolitique - résumé du cours au Collège de France. In Annuaire du Collège de France, 79e année, Histoire des systèmes de pensée, année 1978-1979; Dit et écrits. Vol. III. Paris Editions Gallimard.

Foucault, Michel. 1986. 'Of Other Spaces'. Diacritics 16(Spring 1): 22-27.

Genocchio, Benjamin. 1995. 'Discourse, Discontinuity, Difference: The Question of Other Spaces'. In Postmodern Cities and Spaces, edited by Sophie Watson and Katherine Gibson, 35-46. Oxford: Blackwell.

Goffman, Erwin. 2001. Asylums. Turin: Edizioni Comunità.

Khosrokhavar, Farhad. 2012. The New Arab Revolutions that Shook the World. Boulder, CO: Paradigm.

Laacher, Smaïn. 2005. 'Eléments pour une sociologie de l'exil'. Politix 69: 101-128.

Leroi-Gourhan, André. 1964. Le Geste et la Parole, vol. I. Paris: Technique et Language.

Lynch, Marc, ed. 2012. The Arab Uprising: The Unfinished Revolutions of the New Middle East. New York: Public Affairs.

Mitchell, William J. Tomas. 2002. Landscape and Power. Chicago: The University of Chicago Press.

Sayad, Abdelmalek. 1992. L'immigration et les Paradoxes de L'altérité. Bruxelles: De Boeck Université. 
Simone Maddanu - CADIS - 12/21/2017

\section{A. Esu and S. Maddanu}

Sayad, Abdelmalek. 1999. La Double Absence. Des Illusions de L'émigré aux Souffrances de L'immigré. Paris: Seuil.

Soja, Edward. 1995. 'Heterotopologies: A Remembrance of Other Spaces in the CitadelLA'. In Postmodern Cities and Spaces, edited by Sophie Watson and Katherine Gibson, 13-34. Oxford: Blackwell.

Ricœur, Paul. 1991. 'Evénement et sens'. In Raison Pratique, vol. 2, Paris: EHESS. 